\title{
Pseudomonas moraviensis sp. nov. and Pseudomonas vranovensis sp. nov., soil bacteria isolated on nitroaromatic compounds, and emended description of Pseudomonas asplenii
}

\author{
Ludmila Tvrzová, ${ }^{1}$ Peter Schumann, ${ }^{2}$ Cathrin Spröer, ${ }^{2}$ Ivo Sedláček, ${ }^{3}$ \\ Zdena Páčová, ${ }^{3}$ Ondrej Šedo, ${ }^{4}$ Zbyněk Zdráhal, ${ }^{4}$ Maike Steffen ${ }^{2}$ \\ and Elke Lang ${ }^{2}$ \\ ${ }^{1,3,4}$ Department of Microbiology ${ }^{1}, \mathrm{CCM}$ - Czech Collection of Microorganisms ${ }^{3}$ and Department \\ of Functional Genomics and Proteomics ${ }^{4}$, Institute of Experimental Biology, Faculty of \\ Science, Masaryk University, Tvrdého 14, 60200 Brno, Czech Republic
}

Correspondence

Ludmila Tvrzová

lida@sci.muni.cz
${ }^{2}$ DSMZ - Deutsche Sammlung von Mikroorganismen und Zellkulturen GmbH, Mascheroder Weg 1b, 38124 Braunschweig, Germany
The genus Pseudomonas sensu stricto comprises almost 100 species with validly published names, at the time of writing (Anzai et al., 2000; Hatayama et al., 2005; Park et al., 2005; Peix et al., 2005; Romanenko et al., 2005a, b; Clark et al., 2006). Members of the genus are ubiquitous in soil, water and many other natural habitats (Palleroni, 1992). Due to their ability to utilize a broad spectrum of organic compounds (Stanier et al., 1966), including environmental pollutants (Wackett, 2001), they belong to the biodegrading microflora (Andersen et al., 2000; Fujii et al., 2000; Pandey et al., 2002; Ajithkumar et al., 2003).

\footnotetext{
Abbreviations: 3-F-4-NP, 3-fluoro-4-nitrophenol; MALDI-TOF MS, matrix-assisted laser desorption/ionization-time of flight mass spectrometry.

The GenBank/EMBL/DDBJ accession numbers for the 16S rRNA gene sequences of strains $2 B 2^{\top}$ and $1 B 4^{\top}$ are $A Y 970951$ and AY970952, respectively.

A table detailing characteristic peaks obtained by using intact cell MALDI-TOF MS and micrographs showing flagella staining of cells of Pseudomonas moraviensis $1 \mathrm{~B} 4^{\top}$ and Pseudomonas vranovensis $2 \mathrm{~B}^{\top}$ are available as supplementary material in IJSEM Online.
}

Strains $1 \mathrm{~B} 4^{\mathrm{T}}$ and $2 \mathrm{~B} 2^{\mathrm{T}}$ were isolated from samples of soil that originated from a place exposed to exhaust from motor vehicles in the village of Vranov, in the South Moravian region of the Czech Republic. Mineral medium (MM) described by Kotoučková et al. (2004), supplemented with 3-fluoro-4-nitrophenol (3-F-4-NP), 4-nitroguaiacol, 5methyl-2-nitrophenol, 2-hydroxy-6-nitroaniline and 4,5fluoro-2-nitrobenzoic acid, was used in the first step of enrichment and was followed by the use of 3-F-4-NPsupplemented medium in the second step of isolation. Ten millilitres of the medium supplemented with a mixture of nitroaromatic compounds was inoculated into $100 \mathrm{ml}$ 3-F-4-NP-containing MM. Flasks were shaken on a rotary shaker at $28^{\circ} \mathrm{C}$. When the yellow colour of the medium had disappeared, samples were taken for repeated streaking on MM supplemented with 3-F-4-NP and solidified by addition of $1.5 \%(\mathrm{w} / \mathrm{v})$ agar. Resulting single colonies were examined on nutrient agar (Oxoid CM3) at $28^{\circ} \mathrm{C}$.

Nutrient agar was used for routine cultivation of strains $1 \mathrm{~B} 4^{\mathrm{T}}$ and $2 \mathrm{~B} 2^{\mathrm{T}}$ and closely related type strains. The 
following type strains were used: Pseudomonas jessenii CCM $4840^{\mathrm{T}} \quad\left(=\mathrm{DSM} \quad 17150^{\mathrm{T}}=\mathrm{CIP} 105274^{\mathrm{T}}\right), \quad$ Pseudomonas koreensis DSM $16610^{\mathrm{T}}$, Pseudomonas putida DSM $291^{\mathrm{T}}$ $\left(=\mathrm{CCM} 7156^{\mathrm{T}}\right)$, Pseudomonas asplenii DSM $17133^{\mathrm{T}}$ and Pseudomonas fuscovaginae DSM $7231^{\mathrm{T}}$.

Cell size, morphology and colony appearance of strains $1 \mathrm{~B} 4^{\mathrm{T}}$ and $2 \mathrm{~B} 2{ }^{\mathrm{T}}$ were assessed as described previously (Kotoučková et al., 2004); the temperature range for growth and salt tolerance were determined on nutrient agar. Hydrolysis of Tween 80 and gelatin was tested according to Páčová \& Kocur (1984). Additional biochemical properties were determined by using methods described by Smibert \& Krieg (1994) and by using API 20NE, API 50 CH and Biolog GN MicroPlate systems. The commercial kits were used according to the manufacturers' instructions. Tests were read after 24 and $48 \mathrm{~h}$ with Biolog MicroStation System (MicroLog3 GN 4.20 database) for Biolog and visually for the API strips. Results read after $24 \mathrm{~h}$ are presented in Table 1 and the species description; belated positive reactions of API $20 \mathrm{NE}$ and API $50 \mathrm{CH}$ are given in parentheses.

Genomic DNA extraction, PCR amplification of the 16S rRNA gene and purification of PCR products were carried out as described by Rainey et al. (1996). Purified PCR products were sequenced with a CEQ DTCS Quick Start kit (Beckman Coulter), according to the manufacturer's protocol. The CEQ 8000 Genetic Analysis System was used for electrophoresis of the sequence reaction products. The ae2 editor (Maidak et al., 1999) was used to align the $16 \mathrm{~S}$ rRNA gene sequences of strains $1 \mathrm{~B} 4^{\mathrm{T}}$ and $2 \mathrm{~B} 2^{\mathrm{T}}$ against those of representatives of the main bacterial lineages available from the public databases. Evolutionary distances were calculated using the method of Jukes \& Cantor (1969). Phylogenetic dendrograms were constructed using the neighbour-joining algorithms (De Soete, 1983). Bootstrap analysis was used to evaluate the tree topology by performing 1000 resamplings (Felsenstein, 1993).

DNA for DNA-DNA hybridization experiments was isolated by using a French pressure cell and purified by chromatography on hydroxyapatite as described by Cashion et al. (1977). DNA-DNA reassociation was performed under optimal conditions $\left(2 \times \mathrm{SSC}\right.$ at $\left.67^{\circ} \mathrm{C}\right)$ and recorded using a model Cary 100 Bio UV/VIS-spectrophotometer (Varian) equipped with a Peltier-thermostatted $6 \times 6$ multicell changer and a temperature controller with an in situ temperature probe (Varian; Huß et al., 1983). Automated ribotyping was carried out using the RiboPrinter microbial characterization system (Qualicon; DuPont) and EcoRI to generate restriction fragments.

The matrix-assisted laser desorption/ionization-time of flight mass spectrometry (MALDI-TOF MS) technique was used for additional characterization of the isolates. Samples for MALDI-TOF MS analysis were prepared by suspending the cells in acetonitrile/water $(1: 1, \mathrm{v} / \mathrm{v})$ and analysed immediately. Analyses were performed on a Reflex
IV instrument (Bruker); sDHB (90 \% 2,5-dihydroxybenzoic acid and 10\% 2-hydroxy-5-methoxybenzoic acid; Bruker) was used as a MALDI matrix. Bacterial suspensions were mixed with sDHB matrix solution $\left(40 \mathrm{mg} \mathrm{ml}^{-1}\right.$ in $20 \%$ acetonitrile and $1 \%$ trifluoroacetic acid) in a $1: 4(\mathrm{v} / \mathrm{v})$ ratio. The mixture $(0.6 \mu \mathrm{l})$ was pipetted on the MALDI target using the 'Dried-Droplet' sample preparation technique. Mass spectra measurements were performed in the linear positive mode. Mass spectra were calibrated externally using $[\mathrm{M}+\mathrm{H}]^{+}$and $[\mathrm{M}+2 \mathrm{H}]^{2+}$ molecular ion signals of lysozyme. At least seven consecutive spectra from three spots were measured for each sample. Spectra were evaluated with XTOF data-processing software, version 5.1.5 (Bruker). Peaks present in all measured spectra for a particular sample were taken into account for assessment of strain differences.

Cells for fatty acid analysis were harvested from $24 \mathrm{~h}$ cultures grown at $28{ }^{\circ} \mathrm{C}$ on trypticase soy broth (BBL) solidified by agar (Difco). Fatty acids were extracted and analysed as described by Čechová et al. (2004).

Phylogenetic analysis based on almost complete $16 \mathrm{~S}$ rRNA gene sequences placed strains $1 \mathrm{~B} 4^{\mathrm{T}}$ and $2 \mathrm{~B} 2^{\mathrm{T}}$ in the genus Pseudomonas sensu stricto. The phylogenetic positions on the $16 \mathrm{~S}$ rRNA gene tree are shown in Fig. 1. Strain $1 \mathrm{~B} 4^{\mathrm{T}}$ formed a cluster with $P$. koreensis DSM $16610^{\mathrm{T}}(99 \cdot 5 \%$ gene sequence similarity) and $P$. jessenii CCM $4840^{\mathrm{T}}(99 \cdot 3 \%)$, and strain $2 \mathrm{~B}^{\mathrm{T}}$ with $P$. asplenii DSM $17133^{\mathrm{T}}(98 \cdot 9 \%), P$. fuscovaginae DSM $7231^{\mathrm{T}}(98.9 \%)$ and P. putida DSM $291^{\mathrm{T}}$ $(98 \cdot 7 \%)$. The closest relatives of strains $1 \mathrm{~B}^{\mathrm{T}}$ and $2 \mathrm{~B} 2^{\mathrm{T}}$ (with $16 \mathrm{~S}$ rRNA gene sequence similarity values above $98 \%$ ) were subjected to DNA-DNA hybridization. The DNADNA reassociation values were as follows: $40 \%$ for strain $1 \mathrm{~B} 4^{\mathrm{T}}$ and P. koreensis DSM $16610^{\mathrm{T}}, 46 \%$ for strain $1 \mathrm{~B} 4^{\mathrm{T}}$ and P. jessenii CCM $4840^{\mathrm{T}}$, and 22,12 and $43 \%$, respectively, between strain $2 \mathrm{~B} 2^{\mathrm{T}}$ and $P$. asplenii DSM $17133^{\mathrm{T}}, P$. fuscovaginae DSM $7231^{\mathrm{T}}$ and P. putida DSM $291^{\mathrm{T}}$. The DNA-DNA reassociation values of all closest relatives were clearly below $70 \%$, which is considered to be the threshold value for the delineation of genomic species (Wayne et al., 1987).

As the DNA-DNA hybridization results of all the strains with the highest 16S rRNA gene sequence similarities uniformly showed values that were clearly below the species limit of $70 \%$, it is very unlikely that strains with lower similarity in the $16 \mathrm{~S}$ rRNA gene sequence would reassociate with rates above the species limit. For the genus Pseudomonas, it was shown in previous studies that strains with 16S rRNA gene sequence similarities greater than 98 or even $99 \%$ may belong to different species (Uchino et al., 2001; Behrendt et al., 2003; Hauser et al., 2004). This is also true for groupings depicted in Fig. 1, among species highly related to strains $1 \mathrm{~B} 4^{\mathrm{T}}$ and $2 \mathrm{~B} 2^{\mathrm{T}}$ (Nishimori et al., 2000; Dabboussi et al., 2002; Kwon et al., 2003). As early as 1999, Mohn et al. (1999) set the threshold for species delineation to $98 \%$ similarity of the $16 \mathrm{~S}$ rRNA gene in their description 
Table 1. Characteristics that differentiate Pseudomonas moraviensis sp. nov. $1 \mathrm{~B}^{\top},{ }^{\top}$ seudomonas vranovensis sp. nov. $2 \mathrm{~B} 2^{\top}$ and closely related Pseudomonas species

Strains: 1, P. moraviensis $1 \mathrm{~B} 4^{\mathrm{T}}\left(=\mathrm{CCM} 7280^{\mathrm{T}}\right) ; 2$, P. vranovensis $2 \mathrm{~B} 2^{\mathrm{T}}\left(=\mathrm{CCM} 7279^{\mathrm{T}}\right) ; 3$, P. asplenii DSM $17133^{\mathrm{T}} ; 4$, P. fuscovaginae DSM $7231^{\mathrm{T}}$; 5, P. putida CCM $7156^{\mathrm{T}}$; 6, P. jessenii CCM $4840^{\mathrm{T}}$; 7, P. koreensis DSM $16610^{\mathrm{T}}$. +, Positive reaction; -, negative reaction, W, weakly positive reaction; ND, not determined. Values in parentheses were read after $48 \mathrm{~h}$.

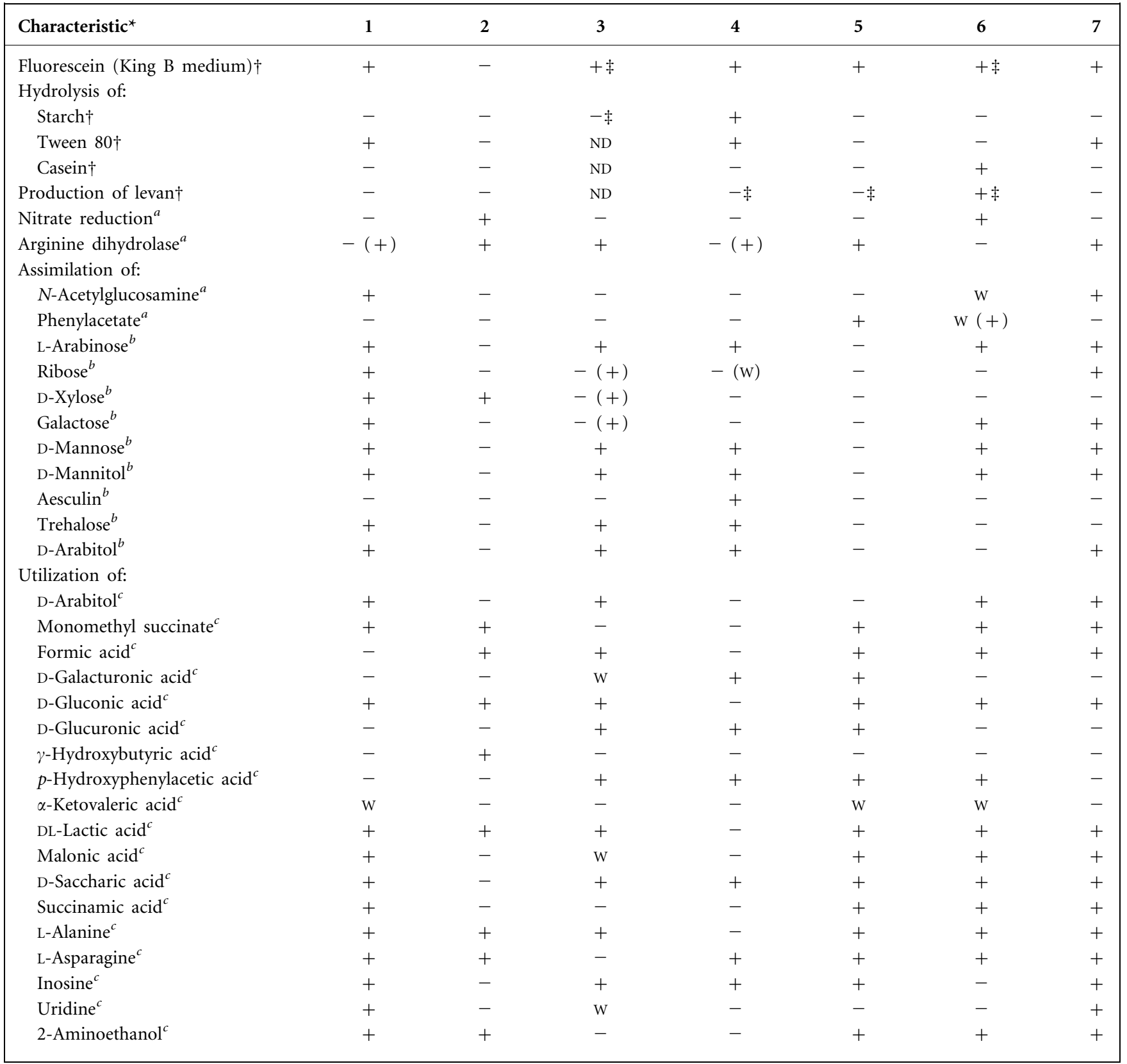

${ }^{\star}$ Designated characteristics were determined with: $a$, API 20NE; $b$, API $50 \mathrm{CH}$; or $c$, Biolog GN.

†Conventional tests according to Smibert \& Krieg (1994) and Páčová \& Kocur (1984).

¥Data from Ark \& Tompkins (1946), Miyajima et al. (1983), Verhille et al. (1999), Sikorski et al. (2001) and Dabboussi et al. (1999).

of Pseudomonas multiresinivorans, Pseudomonas vancouverensis and Pseudomonas abietaniphila.

Pseudomonas oryzihabitans IAM $1568^{\mathrm{T}}$ was not included in the cluster of closely related strains of $2 \mathrm{~B} 2^{\mathrm{T}}$, although it appears to be closely related [16S rRNA gene similarity value of strain $2 \mathrm{~B} 2^{\mathrm{T}}$ with the available $16 \mathrm{~S}$ rRNA gene sequence (GenBank accession no. D84004) is above 98\%]. The results of repeated 16S rRNA gene sequence analyses, performed at the DSMZ and at IAM, show just $95 \cdot 8 \%$ 


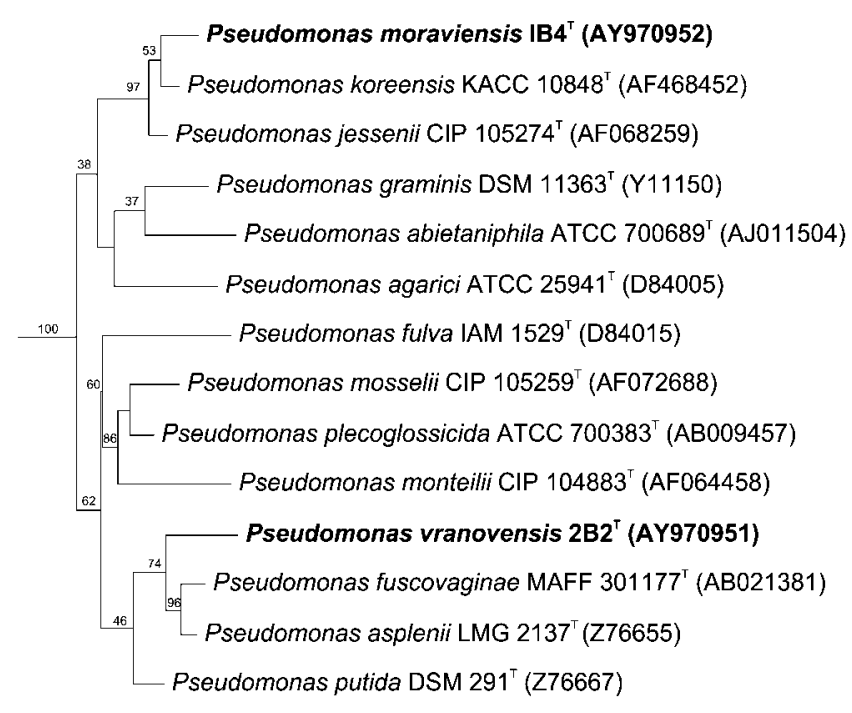

$3 \%$

Fig. 1. Neighbour-joining tree based on 16S rRNA gene sequence analysis showing the phylogenetic position of $P$. moraviensis $\mathrm{sp}$. nov. $1 \mathrm{~B} 4^{\top}$ and $P$. vranovensis sp. nov. $2 \mathrm{~B} 2^{\top}$. Escherichia coli was used to root the dendrogram (not shown). Bootstrap values (expressed as percentages) are given at branching points (1000 resamplings). Bar, 3 nucleotide substitutions per 100 nucleotides.

sequence similarity of $P$. oryzihabitans IAM $1568^{\mathrm{T}}$ (GenBank accession no. AM262973) with the sequence deposited under accession number D84004. The sequence of $P$. oryzihabitans IAM $1568^{\mathrm{T}}$ (AM262973) is identical with that of $P$. oryzihabitans DSM $6835^{\mathrm{T}}$ (not submitted), so we believe that the sequence of $P$. oryzihabitans deposited under accession number D84004 is wrong. Apart from sequence analysis, no further tests were done. Interestingly, the sequence from Pseudomonas oleovorans IAM $1508^{\mathrm{T}}$ (GenBank accession no. D84018) is almost identical to the sequence we obtained for P. oryzihabitans IAM $1568^{\mathrm{T}}$ $(99.6 \%)$, so it is possible that sequences D84004 and D84018 (Anzai et al., 2000) were confused. The $16 \mathrm{~S}$ rRNA gene similarity value of strain $2 \mathrm{~B} 2^{\mathrm{T}}$ and $P$. oryzihabitans IAM $1568^{\mathrm{T}}($ AM262973) was $95 \cdot 2 \%$.

The closely related species were subjected to phenotypic characterization (Table 1). As the description of $P$. asplenii
(Ark \& Tompkins, 1946; Savulescu, 1947) included only a few of the features needed for the present study, the type strain, DSM $17133^{\mathrm{T}} \quad\left(=\right.$ ATCC $23835^{\mathrm{T}}=\mathrm{NCPPB}$ $\left.1947^{\mathrm{T}}=\mathrm{ICMP} 3944^{\mathrm{T}}\right)$, and a second strain, DSM 50254, were studied in detail, resulting in an emended description of the species. MALDI-TOF MS intact cell profile data are given as additional differentiation characteristics for strain $1 \mathrm{~B} 4^{\mathrm{T}}$, its closest relatives and strain $2 \mathrm{~B} 2^{\mathrm{T}}$ (see Supplementary Table S1 in IJSEM Online).

Strain $1 \mathrm{~B} 4^{\mathrm{T}}$ could be differentiated from $P$. jessenii $\mathrm{CCM}$ $4840^{\mathrm{T}}$ by its ability to hydrolyse Tween 80 , assimilate ribose, $\mathrm{D}$-xylose, trehalose and D-arabitol, and utilize inosine and uridine, and by its inability to hydrolyse casein, produce levan or reduce nitrate. Assimilation of D-xylose and trehalose and the inability to utilize formic acid distinguish strain $1 \mathrm{~B} 4^{\mathrm{T}}$ from P. koreensis DSM $16610^{\mathrm{T}}$ (Table 1). MALDI-TOF MS intact cell profile is another characteristic useful for differentiating strain $1 \mathrm{~B} 4^{\mathrm{T}}$ from $P$. jessenii CCM $4840^{\mathrm{T}}$ and P. koreensis DSM $16610^{\mathrm{T}}$ (see Supplementary Table S1 in IJSEM Online). Characteristics that distinquish strain $2 \mathrm{~B} 2^{\mathrm{T}}$ from P. asplenii DSM $17133^{\mathrm{T}}$, P. fuscovaginae DSM $7231^{\mathrm{T}}$ and P. putida CCM $7156^{\mathrm{T}}$ are nitrate reduction, no fluorescein production on King $\mathrm{B}$ medium and utilization of $\gamma$-hydroxybutyric acid but not D-glucuronic acid, p-hydroxyphenylacetic acid or D-saccharic acid. Strains $1 \mathrm{~B} 4^{\mathrm{T}}$ and $2 \mathrm{~B} 2^{\mathrm{T}}$ differed, in addition to the characteristics given in Table 1 , in the utilization of $\mathrm{D}$ galactose, D-galactonic acid lactone and L-ornithine.

Moreover, the RiboPrint patterns of strains $1 \mathrm{~B} 4^{\mathrm{T}}$ and $2 \mathrm{~B} 2^{\mathrm{T}}$ (generated by using EcoRI) differed from those of the type strains of related Pseudomonas species (Fig. 2).

The cellular fatty acid content of strains $1 \mathrm{~B} 4^{\mathrm{T}}$ and $2 \mathrm{~B} 2^{\mathrm{T}}$ was very similar. The following fatty acids were detected for strain $1 \mathrm{~B}^{\mathrm{T}}: 3-\mathrm{OH} \mathrm{C}_{10: 0}, 2 \cdot 6 \% ; \mathrm{C}_{12: 0}, 2 \cdot 1 \% ; 2-\mathrm{OH} \mathrm{C} \mathrm{C}_{12: 0}$, $4 \cdot 9 \%$; 3-OH C $12: 0,4 \cdot 1 \% ; \mathrm{C}_{14: 0}, 0 \cdot 4 \% ; \mathrm{C}_{16: 1} \omega 7 c, 36 \cdot 1 \%$; $\mathrm{C}_{16: 1} \omega 5 c, 0 \cdot 1 \% ; \mathrm{C}_{16: 0}, 28 \cdot 8 \% ; \mathrm{C}_{17: 0}$ iso, $0 \cdot 2 \% ; \mathrm{C}_{17: 0}$ cyclo, $2 \cdot 4 \% ; \mathrm{C}_{17: 0}, 0 \cdot 2 \% ; \mathrm{C}_{18: 1} \omega 7 c, 17 \cdot 3 \% ; \mathrm{C}_{18: 0}, 0 \cdot 5 \%$; and $\mathrm{C}_{19: 0}$ cyclo $\omega 8 c, 0 \cdot 2 \%$.

The cellular fatty acid content of strain $2 \mathrm{~B} 2^{\mathrm{T}}$ was as follows: $\mathrm{C}_{10: 0}, 0 \cdot 1 \% ; 3-\mathrm{OH} \mathrm{C} \mathrm{C}_{10: 0}, 3 \cdot 3 \% ; \mathrm{C}_{12: 0}, 3 \cdot 2 \% ; 2-\mathrm{OH} \mathrm{C} \mathrm{C}_{12: 0}$, $4 \cdot 1 \%$; $3-\mathrm{OH} \mathrm{C} \mathrm{C}_{12: 0}, 3 \cdot 9 \% ; \mathrm{C}_{14: 0}, 0 \cdot 3 \% ; \mathrm{C}_{16: 1} \omega 7 c, 27 \cdot 0 \%$; $2-\mathrm{OH} \mathrm{C}_{15: 0}$ iso, $6.2 \% ; \mathrm{C}_{16: 1} \omega 5 c, 0.1 \% ; \mathrm{C}_{16: 0}, 27 \cdot 0 \%$; $\mathrm{C}_{17: 0}$ iso, $0 \cdot 2 \% ; \mathrm{C}_{17: 1} \omega 8 c, 0 \cdot 2 \% ; \mathrm{C}_{17: 0}$ cyclo, $5 \cdot 0 \% ; \mathrm{C}_{17: 0}$,
Pseudomonas jessenii DSM $17150^{\top}$ Pseudomonas asplenii DSM $17133^{\top}$ Pseudomonas moraviensis $1 \mathrm{~B}^{\top}{ }^{\top}$ Pseudomonas fuscovaginae DSM $7231^{\top}$ Pseudomonas koreensis DSM $16610^{\top}$ Pseudomonas putida DSM $291^{\top}$ Pseudomonas vranovensis $2 \mathrm{~B}^{\top}{ }^{\top}$
Fig. 2. RiboPrint patterns generated by using EcoRl for strains $1 \mathrm{~B} 4^{\top}, 2 \mathrm{~B} 2^{\top}$ and phylogenetically related type strains. The dendrogram of pattern similarity was calculated by using BioNumerics software (Applied Maths). 
$0 \cdot 3 \% ; \mathrm{C}_{18: 1} \omega 7 c, 18 \cdot 5 \% ; \mathrm{C}_{18: 0}, 0 \cdot 4 \%$; and $\mathrm{C}_{19: 0}$ cyclo $\omega 8 c$, $0 \cdot 1 \%$.

Genetic and chemotaxonomic methods such as 16S rRNA gene analysis, DNA-DNA hybridization and whole-cell fatty acid analysis placed the two strains in the genus Pseudomonas sensu stricto. On the basis of genetic and phenotypic characteristics that distinguish strains $1 \mathrm{~B} 4^{\mathrm{T}}$ and $2 \mathrm{~B} 2^{\mathrm{T}}$ from their closest relatives, two novel species are proposed with the names Pseudomonas moraviensis sp. nov. and Pseudomonas vranovensis sp. nov.

Additional data generated for the type strain DSM $17133^{\mathrm{T}}$ and strain DSM 50254 of $P$. asplenii for comparative purposes in this study resulted in an emended description of this species.

\section{Description of Pseudomonas moraviensis sp. nov.}

Pseudomonas moraviensis (mo.ra.vi'en.sis. N.L. fem. adj. moraviensis pertaining to Moravia, the region of the Czech Republic where strain $1 \mathrm{~B} 4^{\mathrm{T}}$ was isolated).

Cells are Gram-negative, non-spore-forming rods, $0 \cdot 6-1 \cdot 3 \times 2-5 \mu \mathrm{m}$, occurring singly or in pairs and motile by polar flagella (see Supplementary Fig. S1a in IJSEM Online). Cells form long rods $(5-10 \mu \mathrm{m})$ in liquid medium (nutrient broth). Colonies on nutrient agar are circular, smooth and 2-3 $\mathrm{mm}$ in diameter (after $24 \mathrm{~h}$ of cultivation). Fluorescein is produced on King B medium. Pyocyanine is not produced on King A medium. Growth occurs at $4-35^{\circ} \mathrm{C}$, with optimum growth at $28-35^{\circ} \mathrm{C}$. Oxidasepositive. Urease- and DNase-negative. Nitrate reduction is negative. Tween 80 , gelatin and tyrosine are hydrolysed, but not aesculin or starch. Lecithinase and indole are not produced and levan is not formed. By API 20NE, $\beta$ galactosidase is not produced and fermentation of D-glucose and assimilation of adipate are negative. Caprate, malate and citrate are assimilated. The following carbohydrates are assimilated (API $50 \mathrm{CH}$ ): glycerol, L-arabinose, D-glucose, D-fructose, D-trehalose, D-lyxose (weakly positive after $96 \mathrm{~h}$ ), gluconate and 2-ketogluconate. Negative reactions (API $50 \mathrm{CH}$ ) were observed for erythritol, D-arabinose, Lxylose, D-adonitol, methyl $\beta$-xyloside, L-sorbose, L-rhamnose, dulcitol, inositol, D-sorbitol, methyl $\alpha$-D-mannoside, methyl $\alpha$-D-glucoside, amygdalin, arbutin, salicin, Dcellobiose, D-maltose, D-lactose, D-melibiose, D-sucrose, inulin, D-melezitose, D-raffinose, starch, glycogen, xylitol, gentiobiose, D-turanose, D-tagatose, D-fucose, L-fucose, Larabitol and 5-ketogluconate. The following compounds are utilized (Biolog system): Tween 40, Tween 80, L-arabinose, D-fructose, D-galactose, $\alpha$-D-glucose, D-mannitol, D-mannose, D-psicose, D-trehalose, methyl pyruvate, acetic acid, cis-aconitic acid, citric acid, formic acid, D-galactonic acid lactone, D-glucosaminic acid, $\alpha$-hydroxybutyric acid, $\beta$ hydroxybutyric acid, $\alpha$-ketoglutaric acid, $\alpha$-ketovaleric acid, propionic acid, quinic acid, succinic acid, bromosuccinic acid, L-alaninamide, D-alanine, L-alanyl glycine, L-aspartic acid, L-glutamic acid, L-histidine, hydroxy-L-proline, Lleucine, L-pyroglutamic acid, L-serine, L-threonine, DLcarnitine, $\gamma$-aminobutyric acid, urocanic acid, glycerol and DL- $\alpha$-glycerol phosphate. Negative reactions (Biolog) are observed with $\alpha$-cyclodextrin, dextrin, $N$-acetyl-Dgalactosamine, adonitol, D-cellobiose, erythritol, L-fucose, gentiobiose, myo-inositol, $\alpha$-D-lactose, lactulose, maltose, D-melibiose, methyl $\beta$-D-glucoside, D-raffinose, L-rhamnose, D-sorbitol, sucrose, turanose, xylitol, itaconic acid, sebacic acid, glycyl L-aspartic acid, L-ornithine, L-phenylalanine, D-serine, thymidine, phenylethylamine, 2,3-butanediol, $\alpha$-D-glucose 1-phosphate and D-glucose 6-phosphate. Other reactions determined by API 20NE, API $50 \mathrm{CH}$ and Biolog systems are given in Table 1 . The fatty acid pattern is characterized by the presence of hydroxy fatty acids and cyclopropane fatty acids.

The type strain, $1 \mathrm{~B} 4^{\mathrm{T}}\left(=\mathrm{CCM} 7280^{\mathrm{T}}=\mathrm{DSM} 16007^{\mathrm{T}}\right)$, was isolated from soil.

\section{Description of Pseudomonas vranovensis sp. nov.}

Pseudomonas vranovensis (vra.no.ven'sis. N.L. fem. adj. vranovensis of/from Vranov, the name of a village in South Moravia, the place of soil origin, the source of isolation of strain $2 \mathrm{~B} 2^{\mathrm{T}}$ ).

Cells are Gram-negative, non-spore-forming rods, $1-1 \cdot 5 \times 2-4 \mu \mathrm{m}$, occurring typically in pairs and motile by polar flagella (see Supplementary Fig. S1b in IJSEM Online). Colonies on nutrient agar are circular, smooth, non-pigmented and 2-3 $\mathrm{mm}$ in diameter (after $24 \mathrm{~h}$ of cultivation). Production of fluorescein (King B medium) and pyocyanine (King A medium) is negative. Growth occurs at $4-35^{\circ} \mathrm{C}$, with optimum growth at $28-35^{\circ} \mathrm{C}$. Growth occurs in up to $5 \% \mathrm{NaCl}$. Oxidase-positive. Ureaseand DNase-negative. Nitrate is reduced to nitrite. Nitrite is not reduced. Tween 80, gelatin, aesculin and starch are not hydrolysed. Lecithinase is not produced and levan is not formed. Tyrosine is hydrolysed. Indole is not produced. By API 20NE, arginine dihydrolase is produced but not $\beta$-galactosidase, and fermentation of $\mathrm{D}$-glucose and assimilation of adipate and phenylacetate are negative. Caprate, malate and citrate are assimilated. The following carbohydrates are assimilated (API $50 \mathrm{CH}$ ): glycerol, Dglucose, $\mathrm{D}$-fructose and gluconate. Negative reactions were obtained for erythritol, D-arabinose, L-arabinose, L-xylose, adonitol, methyl $\beta$-xyloside, L-sorbose, L-rhamnose, dulcitol, inositol, D-sorbitol, methyl $\alpha$-D-mannoside, methyl $\alpha$-Dglucoside, $N$-acetylglucosamine, amygdalin, arbutin, salicin, D-cellobiose, D-maltose, D-lactose, D-melibiose, D-sucrose, inulin, D-melezitose, D-raffinose, starch, glycogen, xylitol, gentiobiose, D-turanose, D-lyxose, D-tagatose, D-fucose, L-fucose, L-arabitol, 2-ketogluconate and 5-ketogluconate. The following compounds are utilized (Biolog system): Tween 80 , D-fructose, $\alpha$-D-glucose, methyl pyruvate, acetic acid, cis-aconitic acid, citric acid, formic acid, $\beta$-hydroxybutyric acid, $\alpha$-ketoglutaric acid, propionic 
acid, quinic acid, succinic acid, bromosuccinic acid, Lalaninamide, D-alanine, L-aspartic acid, L-glutamic acid, L-histidine, hydroxy-L-proline, L-leucine, L-ornithine, Lproline, L-pyroglutamic acid, D-serine, L-serine, DLcarnitine, $\gamma$-aminobutyric acid, urocanic acid, putrescine and glycerol. Negative reactions (Biolog) were observed with $\alpha$-cyclodextrin, dextrin, $N$-acetyl-D-galactosamine, $N$ acetyl-D-glucosamine, adonitol, L-arabinose, D-cellobiose, erythritol, L-fucose, D-galactose, gentiobiose, myo-inositol, $\alpha$-D-lactose, lactulose, maltose, D-mannitol, D-mannose, Dmelibiose, methyl $\beta$-D-glucoside, D-psicose, D-raffinose, Lrhamnose, D-sorbitol, sucrose, D-trehalose, turanose, xylitol, D-galactonic acid lactone, D-glucosaminic acid, itaconic acid, sebacic acid, glucuronamide, L-alanyl glycine, glycyl L-aspartic acid, glycyl L-glutamic acid, Lphenylalanine, thymidine, phenylethylamine, 2,3-butanediol, DL- $\alpha$-glycerol phosphate, $\alpha$-D-glucose 1 -phosphate and D-glucose 6-phosphate. Other reactions determined by API 20NE, API $50 \mathrm{CH}$ and Biolog systems are given in Table 1. The fatty acid pattern is characterized by the presence of hydroxy fatty acids and cyclopropane fatty acids.

The type strain, $2 \mathrm{~B} 2^{\mathrm{T}}\left(=\mathrm{CCM} 7279^{\mathrm{T}}=\mathrm{DSM} 16006^{\mathrm{T}}\right)$, was isolated from soil.

\section{Emended description of Pseudomonas asplenii (Ark and Tompkins 1946) Savulescu 1947}

Has the following properties in addition to those given previously (Ark \& Tompkins, 1946). Oxidase-positive. By API $20 \mathrm{NE}$, indole and $\beta$-galactosidase are not produced, aesculin and gelatin are not hydrolysed and fermentation of D-glucose and assimilation of adipate are negative. Caprate, malate and citrate are assimilated. Assimilation (API $50 \mathrm{CH}$ ) is positive for glycerol, D-glucose, D-fructose and gluconate, and negative for erythritol, D-arabinose, L-xylose, adonitol, methyl $\beta$-xyloside, L-sorbose, L-rhamnose, dulcitol, inositol, D-sorbitol, methyl $\alpha$-D-mannoside, methyl $\alpha$-D-glucoside, $N$-acetylglucosamine, amygdalin, arbutin, salicin, D-cellobiose, D-maltose, D-lactose, D-melibiose, D-sucrose, inulin, D-melezitose, D-raffinose, starch, glycogen, xylitol, gentiobiose, D-turanose, D-lyxose, D-tagatose, D-fucose, L-fucose, L-arabitol, 2-ketogluconate and 5-ketogluconate. The following compounds are utilized (Biolog system): methyl pyruvate, cis-aconitic acid, citric acid, formic acid, $\beta$ hydroxybutyric acid, $p$-hydroxyphenylacetic acid, $\alpha$-ketoglutaric acid, quinic acid, bromosuccinic acid, D-alanine, L-aspartic acid, L-glutamic acid, L-histidine, hydroxy-Lproline, L-proline, L-serine, DL-carnitine, $\gamma$-aminobutyric acid and urocanic acid. Negative reactions (Biolog system) are observed with $\alpha$-cyclodextrin, dextrin, glycogen, Tween 40, $N$-acetyl-D-galactosamine, adonitol, D-cellobiose, erythritol, L-fucose, gentiobiose, myo-inositol, $\alpha$-D-lactose, lactulose, maltose, D-melibiose, methyl $\beta$-D-glucoside, D-psicose, D-raffinose, L-rhamnose, D-sorbitol, sucrose, D-trehalose, turanose, xylitol, D-galactonic acid lactone, $\gamma$-hydroxybutyric acid, itaconic acid, $\alpha$-ketobutyric acid, sebacic acid, glucuronamide, glycyl L-aspartic acid, L-leucine, L-phenylalanine, L-pyroglutamic acid, D-serine, phenylethylamine, putrescine, 2,3-butanediol, $\alpha$-D-glucose 1-phosphate and D-glucose 6-phosphate. Other reactions determined by API 20NE, API $50 \mathrm{CH}$ and Biolog systems are given in Table 1.

The type strain is DSM $17133^{\mathrm{T}}\left(=\mathrm{ATCC} 23835^{\mathrm{T}}=\mathrm{CIP}\right.$ $\left.106710^{\mathrm{T}}\right)$.

\section{Acknowledgements}

We are grateful to $\mathrm{H}$. Trüper, University of Bonn, Germany, for his help with the Latin construction of the species epithet. We also thank A. Vester, I. Kramer, G. Pötter and A. Frühling (DSMZ) for excellent technical assistance. This work was supported by the Ministry of Education of the Czech Republic (project nos MSM0021622413, MSM0021622415 and MSM0021622416).

\section{References}

Ajithkumar, B., Ajithkumar, V. P. \& Iriye, R. (2003). Degradation of 4-amylphenol and 4-hexylphenol by a new activated sludge isolate of Pseudomonas veronii and proposal for a new subspecies status. Res Microbiol 154, 17-23.

Andersen, S. M., Johnsen, K., Sørensen, J., Nielsen, P. \& Jacobsen, C. S. (2000). Pseudomonas frederiksbergensis sp. nov., isolated from soil at a coal gasification site. Int J Syst Evol Microbiol 50, 1957-1964.

Anzai, Y., Kim, H., Park, J.-Y., Wakabayashi, H. \& Oyaizu, H. (2000). Phylogenetic affiliation of the pseudomonads based on 16S rRNA sequence. Int J Syst Evol Microbiol 50, 1563-1589.

Ark, P. A. \& Tompkins, C. M. (1946). Bacterial leaf blight of bird'snest fern. Phytopathology 36, 758-761.

Behrendt, U., Ulrich, A. \& Schumann, P. (2003). Fluorescent pseudomonads associated with the phyllosphere of grasses; Pseudomonas trivialis sp. nov., Pseudomonas poae sp. nov. and Pseudomonas congelans sp. nov. Int J Syst Evol Microbiol 53, 1461-1469.

Cashion, P., Holder-Franklin, M. A., McCully, J. \& Franklin, M. (1977). A rapid method for the base ratio determination of bacterial DNA. Anal Biochem 81, 461-466.

Clark, L. L., Dajcs, J. J., McLean, C. H., Bartell, J. G. \& Stroman, D. W. (2006). Pseudomonas otitidis sp. nov., isolated from patients with otic infections. Int J Syst Evol Microbiol 56, 709-714.

Čechová, L., Durnová, E., Šikutová, S., Halouzka, J. \& Němec, M. (2004). Characterization of spirochetal isolates from arthropods collected in South Moravia, Czech Republic, using fatty acid methyl esters analysis. J Chromatogr B 808, 248-254.

Dabboussi, F., Hamze, M., Elomari, M., Verhille, S., Baida, N., Izard, D. \& Leclerc, H. (1999). Taxonomic study of bacteria isolated from Lebanese spring waters: proposal for Pseudomonas cedrella sp. nov. and P. orientalis sp. nov. Res Microbiol 150, 303-316.

Dabboussi, F., Hamze, M., Singer, E., Geoffroy, V., Meyer, J.-M. \& Izard, D. (2002). Pseudomonas mosselii sp. nov., a novel species isolated from clinical specimens. Int J Syst Evol Microbiol 52, 363 376.

De Soete, G. (1983). A least squares algorithm for fitting additive trees to proximity data. Psychometrika 48, 621-626.

Felsenstein, J. (1993). PHYLIP (phylogeny inference package), version 3.5c. Distributed by the author. Department of Genome Sciences, University of Washington, Seattle, USA.

Fujii, K., Urano, N., Ushio, H., Satomi, M., lida, H., Ushio-Sata, N. \& Kimura, S. (2000). Profile of a nonylphenol-degrading microflora and its potential for bioremedial applications. J Biochem 128, 909-916. 
Hatayama, K., Kawai, S., Shoun, H., Ueda, Y. \& Nakamura, A. (2005). Pseudomonas azotifigens sp. nov., a novel nitrogen-fixing bacterium isolated from a compost pile. Int J Syst Evol Microbiol 55, 1539-1544.

Hauser, E., Kämpfer, P. \& Busse, H.-J. (2004). Pseudomonas psychrotolerans sp. nov. Int J Syst Evol Microbiol 54, 1633-1637.

Huß, V. A. R., Festl, H. \& Schleifer, K. H. (1983). Studies on the spectrophotometric determination of DNA hybridization from renaturation rates. Syst Appl Microbiol 4, 184-192.

Jukes, T. H. \& Cantor, C. R. (1969). Evolution of protein molecules. In Mammalian Protein Metabolism, pp. 21-132. Edited by H. N. Munro. New York: Academic Press.

Kotoučková, L., Schumann, P., Durnová, E., Spröer, C., Sedláček, I., Neča, J., Zdráhal, Z. \& Němec, M. (2004). Arthrobacter nitroguajacolicus sp. nov., a novel 4-nitroguaiacol degrading actinobacterium. Int J Syst Evol Microbiol 54, 773-777.

Kwon, S. W., Kim, J. S., Park, I. C., Yoon, S. H., Park, D. H., Lim, C. K. \& Go, S. J. (2003). Pseudomonas koreensis sp. nov., Pseudomonas umsongensis sp. nov. and Pseudomonas jinjuensis sp. nov., novel species from farm soils in Korea. Int J Syst Evol Microbiol 53, 21-27.

Maidak, B. L., Cole, J. R., Parker, C. T., Jr \& 11 other authors (1999). A new version of the RDP (Ribosomal Database Project). Nucleic Acids Res 27, 171-173.

Miyajima, K., Tanii, A. \& Akita, T. (1983). Pseudomonas fuscovaginae sp. nov., nom. rev. Int J Syst Bacteriol 33, 656-657.

Mohn, W. W., Wilson, A. E., Bicho, P. \& Moore, E. R. B. (1999). Physiological and phylogenetic diversity of bacteria growing on resin acids. Syst Appl Microbiol 22, 68-78.

Nishimori, E., Kita-Tsukamoto, K. \& Wakabayashi, H. (2000). Pseudomonas plecoglossicida sp. nov., the causative agent of bacterial haemorrhagic ascites of ayu, Plecoglossus altivelis. Int J Syst Evol Microbiol 50, 83-89.

Páčová, Z. \& Kocur, M. (1984). New medium for detection of esterase and gelatinase activity. Zentralbl Bakteriol Mikrobiol Hyg $[A]$ 258, 69-73.

Palleroni, N. J. (1992). Introduction to the family Pseudomonadaceae. In The Prokaryotes, 2nd edn, pp. 3071-3085. Edited by A. Balows, H. G. Trüper, M. Dworkin, W. Harder \& K.-H. Schleifer. New York: Springer.

Pandey, K. K., Mayilraj, S. \& Chakrabarti, T. (2002). Pseudomonas indica sp. nov., a novel butane-utilizing species. Int $J$ Syst Evol Microbiol 52, 1559-1567.

Park, Y.-D., Lee, H. B., Yi, H., Kim, Y., Bae, K. S., Choi, J. E., Jung, H. S. \& Chun, J. (2005). Pseudomonas panacis sp. nov., isolated from the surface of rusty roots of Korean ginseng. Int J Syst Evol Microbiol 55, 1721-1724.
Peix, A., Berge, O., Rivas, R., Abril, A. \& Velázquez, E. (2005). Pseudomonas argentinensis sp. nov., a novel yellow pigmentproducing bacterial species, isolated from rhizospheric soil in Córdoba, Argentina. Int J Syst Evol Microbiol 55, 1107-1112.

Rainey, F. A., Ward-Rainey, N., Kroppenstedt, R. M. \& Stackebrandt, E. (1996). The genus Nocardiopsis represents a phylogenetically coherent taxon and a distinct actinomycete lineage: proposal of Nocardiopsaceae fam. nov. Int J Syst Bacteriol 46, 1088-1092.

Romanenko, L. A., Uchino, M., Falsen, E., Frolova, G. M., Zhukova, N. V. \& Mikhailov, V. V. (2005a). Pseudomonas pachastrellae sp. nov., isolated from a marine sponge. Int J Syst Evol Microbiol 55, 919-924.

Romanenko, L. A., Uchino, M., Falsen, E., Lysenko, A. M., Zhukova, N. V. \& Mikhailov, V. V. (2005b). Pseudomonas xanthomarina sp. nov., a novel bacterium isolated from marine ascidian. I Gen Appl Microbiol 51, 65-71.

Savulescu, T. (1947). Contribution à la classification des bacteriacées phytopathogènes. Analele Academiei Romane Series III Tom 22, Memoire 4, 1-26 (in French).

Sikorski, J., Stackebrandt, E. \& Wackernagel, W. (2001). Pseudomonas kilonensis sp. nov., a bacterium isolated from agricultural soil. Int J Syst Evol Microbiol 51, 1549-1555.

Smibert, R. M. \& Krieg, N. R. (1994). Phenotypic characterization. In Methods for General and Molecular Bacteriology, pp. 607-654. Edited by P. Gerhardt. Washington, DC: American Society for Microbiology.

Stanier, R. Y., Palleroni, N. J. \& Doudoroff, N. (1966). The aerobic pseudomonads: a taxonomic study. J Gen Microbiol 43, 159-271.

Uchino, M., Shida, O., Uchimura, T. \& Komagata, K. (2001). Recharacterization of Pseudomonas fulva Iizuka and Komagata 1963, and proposals of Pseudomonas parafulva sp. nov. and Pseudomonas cremoricolorata sp. nov. J Gen Appl Microbiol 46, 247-261.

Verhille, S., Baida, N., Dabboussi, F., Izard, D. \& Leclerc, H. (1999). Taxonomic study of bacteria isolated from natural mineral waters: proposal of Pseudomonas jessenii sp. nov. and Pseudomonas mandelii sp. nov. Syst Appl Microbiol 22, 45-58.

Wackett, L. P. (2001). The metabolic pathways of biodegradation. In The Prokaryotes: an Evolving Electronic Resource for the Microbiological Community, 3rd edn, release 3.6, 22 June 2001. Edited by M. Dworkin, S. Falkow, E. Rosenberg, K.-H. Schleifer \& E. Stackebrandt. New York: Springer. http://141.150.157.117:8080/ prokPUB/index.htm

Wayne, L. G., Brenner, D. J., Colwell, R. R. \& 9 other authors (1987). International committee on systematic bacteriology. Report of the ad hoc committee on reconciliation of approaches to bacterial systematics. Int J Syst Bacteriol 37, 463-464. 